\title{
HUBUNGAN ANTARA WAKTU PEMOTONGAN DENGAN WAKTU PEMESINAN BUBUT PADA UJI KOMPETENSI PRAKTIK KEJURUAN BIDANG PEMESINAN
}

\author{
Aditya Nugraha ${ }^{1}$, Wardaya $^{2}$, Purnawan ${ }^{3}$ \\ Departemen Pendidikan Teknik Mesin \\ Universitas Pendidikan Indonesia \\ Jl. Dr. Setiabudhi No. 207 Bandung 40154 \\ adityanugraha_pp09@yahoo.com
}

\begin{abstract}
ABSTRAK
Latar belakang penelitian ini adalah tidak adanya waktu standar yang spesifik pada aspek waktu pemesinan bubut. Penelitian ini bertujuan untuk mengetahui gambaran waktu pemotongan dan waktu pemesinan serta mengetahui seberapa besar hubungan antara waktu pemotongan dengan waktu pemesinan pada pelaksanaan uji kompetensi praktik kejuruan bidang pemesinan bubut di SMK Negeri 6 Bandung Tahun Pelajaran 2013/2014. Metode yang digunakan pada penelitian ini adalah metode deskriptif korelasional dengan subjek penelitian sebanyak 30 siswa. Data dijaring melalui studi observasi secara langsung pada pelaksanaan uji kompetensi praktik kejuruan teknik pemesinan untuk pekerjaan membubut, yang meliputi membubut rata, bertingkat, tirus, chamfer, alur, ulir, bor dan kartel. Hasil penelitian menunjukan bahwa waktu pemotongan berhubungan dengan waktu pemesinan pada uji kompetensi praktik kejuruan bidang pemesinan bubut dengan tingkat hubungan kuat.
\end{abstract}

Kata kunci: waktu pemotongan, waktu pemesinan, uji kompetensi, kejuruan

\section{PENDAHULUAN}

Pelaksanaan uji kompetensi merupakan salah satu standar kelulusan siswa di SMK. Tujuan dari penilaian kompetensi adalah untuk menetapkan keberhasilan peserta didik dalam menguasai satu unit kompetensi dengan mengacu kepada standar kompetensi nasional. Standar Kompetensi adalah kemampuan yang secara umum harus dimiliki oleh peserta didik (lulusan) (Triyono, 2012).

Standar penilaian pelaksanaan uji kompetensi telah ditentukan oleh Badan Standar Nasional Pendidikan (BSNP). Kriteria yang dinilai pada pelaksanaan uji kompetensi praktik kejuruan meliputi aspek persiapan kerja, proses (sistematika dan cara kerja), hasil kerja, sikap kerja dan waktu. Kelima aspek tersebut menjadi standar acuan penilaian pada proses ujian kompetensi kejuruan (Dimyanti dan Mudjiono, 2013). Indikator pencapaian lembar penilaian yang tercantum pada tabel 1 .

\footnotetext{
${ }^{1}$ Mahasiswa Departemen Pendidikan Teknik Mesin FPTK UPI

${ }^{2}$ Dosen Departemen Pendidikan Teknik Mesin FPTK UPI

${ }^{3}$ Dosen Departemen Pendidikan Teknik Mesin FPTK UPI
} 
Tabel 1 Kriteria Penilaian Waktu Ujian Praktik Kejuruan

\begin{tabular}{llc}
\hline \multicolumn{1}{c}{ Waktu } & \multicolumn{1}{c}{ Kriteria } & Skor \\
\hline Waktu & Selesai tepat waktu dengan hasil baik dan benar & 4 \\
penyelesaian & Selesai tepat waktu dengan hasil kurang baik namun benar & 3 \\
& Selesai tidak tepat waktu dengan hasil baik dan benar & 2 \\
& Selesai tidak tepat waktu dengan kurang baik dan salah & 1 \\
& Tidak selesai & 0 \\
\hline
\end{tabular}

(Sumber: BSNP)

Letak permasalahan adalah dalam kriteria penilaian aspek waktu dan aspek hasil masih disatukan. Padahal dalam lembar perhitungan nilai praktik yang ditentukan BSNP sudah jelas bahwa penilaian aspek hasil kerja dan aspek waktu terpisah. Permasalahan kedua terjadi dalam kriteria penilaian waktu ujian praktik ada aspek waktu terdapat siswa yang selesai tidak tepat waktu masih diberi skor. Sehingga timbul masalah, adanya siswa yang kurang memperhatikan waktu untuk menyelesaikan pekerjaannya. Ini bisa disebabkan mereka tidak tahu berapa waktu standar yang dibutuhkan untuk proses membuat produk dalam uji kompetensi praktik kejuruan bidang pemesinan (Fajaryati, 2012).

Hasil penelitian terdahulu mengenai analisis waktu pemesinan pada uji kompetensi praktik kejuruan bidang pemesinan bubut di SMKN 6 Bandung. Waktu pemesinan pada uji kompetensi kejuruan bidang pemesinan bubut siswa dalam uji kompetensi praktik kejuruan, sebagai berikut: tercepat 85 menit, terlambat 390 menit dan rata-data 213 menit. Secara perhitungan teoritis waktu pemesinan yang dibutuhkan untuk menyelesaikan produk dengan menggunakan mesin bubut adalah selama 132 menit (2 jam 12 menit) dengan selisih waktu rata-rata sebesar 81 menit (1 jam 21 menit). Waktu pemesinan yang dilakukan oleh beberapa siswa terbilang lebih lama dibandingkan dengan perhitungan teoritis.

Waktu pemesinan di pengaruhi oleh waktu aktif pemotongan sebesar 36,2\% (Rochim,1993). Sehingga dapat diasumsikan bahwa waktu pemotongan dapat mempengaruhi waktu pemesinan yang dilakukan oleh siswa dalam proses pemesinan pada saat uji kompetensi bidang pemesinan bubut. Tujuan penelitian ini untuk mengetahui gambaran waktu pemotongan dan waktu pemesinan, serta mengetahui seberapa besar hubungan antara waktu pemotongan dengan waktu pemesinan pada uji kompetensi praktik kejuruan di SMK Negeri 6 Bandung dalam bidang pemesinan bubut. 


\section{METODE PENELITIAN}

Metode yang digunakan dalam penelitian ini adalah deskriptif korelasional. Terdapat dua variabel dalam penelitian ini, yaitu variabel independen $(\mathrm{X})$ yaitu waktu pemotongan praktik kejuruan bidang pemesinan, sedangkan variabel dependen (Y), yaitu waktu pemesinan praktik kejuruan bidang pemesinan. Populasi yang diteliti merupakan siswa tingkat XII tahun 2013/2014 dalam satu angkatan dengan jumlah 120 siswa yang terdiri dari 4 kelas, jumlah siswa tiap kelasnya 29-31 siswa. Sampel yang diambil sebanyak 30 siswa peserta uji kompetensi praktik kejuruan Tahun Pelajaran 2013/2014.

\section{HASIL PENELITIAN}

Hasil penelitian telah diperoleh dengan disarikan ke dalam tabel dibawah ini. Tabel 3. Hasil penelitian

\begin{tabular}{|c|c|c|c|}
\hline \multirow{2}{*}{\multicolumn{2}{|c|}{ Data Penelitian }} & \multicolumn{2}{|c|}{ Waktu Hasil Uji Kompetensi } \\
\hline & & $\begin{array}{l}\text { Waktu Pemotongan } \\
\text { (X) }\end{array}$ & $\begin{array}{l}\text { Waktu Pemesinan } \\
\text { (Y) }\end{array}$ \\
\hline \multirow{2}{*}{$\begin{array}{l}\text { Uji Normalitas } \\
\text { (Kolmogrov Smirnov) }\end{array}$} & Signifikasi & $\begin{array}{c}p \text {-value }<\alpha \\
(0,004<0,05)\end{array}$ & $\begin{array}{c}p \text {-value }>\alpha \\
(0,200>0,05)\end{array}$ \\
\hline & Kondisi & Tidak Normal & Normal \\
\hline \multirow{2}{*}{$\begin{array}{l}\text { Koefisien Korelasi } \\
\text { (Spearman's) }\end{array}$} & Nilai $r$ & \multicolumn{2}{|c|}{$\mathrm{r}=0,60$} \\
\hline & $\begin{array}{l}\text { Tingkat } \\
\text { Hubungan }\end{array}$ & \multicolumn{2}{|c|}{ Kuat } \\
\hline Pengujian Hipotesis & $\begin{array}{l}\text { Nilai sig. } \\
\text { Kondisi }\end{array}$ & \multicolumn{2}{|c|}{$\begin{array}{c}\text { Nilai } \mathrm{Sig}=0,000<\text { Taraf } \mathrm{Sig}=0,05 \\
\text { Ho ditolak dan Ha diterima }\end{array}$} \\
\hline
\end{tabular}

Uji normalitas data dilakukan untuk mengetahui apakah data yang didapat berdistribusi normal atau tidak. Uji normalitas ini dilakukan pada kedua variabel yaitu waktu pemotongan dan waktu pemesinan. Pada penelitian ini, pengujian normalitas menggunakan Test Kolmogorov-Smirnov. Dengan taraf kesalahan $(\alpha)$ sebasar 0,05. Pada hasil perhitungan uji normalitas yang tertera pada tabel 3 analisis data diatas menunjukan bahwa, data waktu pemotongan berdistribusi tidak normal karena p-value $<\alpha(0,004<$ 0,05). Sedangkan pada data waktu pemesinan menujukan bahwa data berdistribusi normal karena $p$-value $>\alpha(0,200>0,05)$. Dengan demikian, dapat diketahui apabila salah satu pendistribusian datanya tidak normal maka penelitian ini mengacu pada penelitian nonparametrik.

Uji koefisien korelasi dilakukan untuk mengetahui tingkat hubungan antara waktu pemotongan dengan waktu pemesinan pada uji kompetensi kejuruan bidang pemesinan bubut. Berdasarkan hasil analisis data yang telah dilakukan, diperoleh harga koefisien korelasi sebesar 0,599. Diketahui bahwa harga koefisien korelasi yang ditemukan sebesar 
0,599 dengan harga pembulatan menjadi 0,60 berada pada kategori kuat. Sehingga terdapat hubungan kuat antara waktu pemotongan dengan waktu pemesinan pada uji kompetensi kejuruan bidang pemesinan bubut.

Uji hipotesis dilakukan untuk menguji kebenaran atas hipotesis yang telah dilakukan sebelumnya apakah diterima atau ditolak. Untuk pengambilan keputusan diketahui bahwa apabila nilai signifikansi $<$ taraf signifikansi $(\alpha)=0,05$ maka $\mathrm{H}_{0}$ ditolak dan $\mathrm{H}_{\mathrm{A}}$ diterima. Sehingga dapat disimpulkan bahwa waktu pemotongan berhubungan dengan waktu pemesinan pada uji kompetensi praktik kejuruan bidang pemesinan.

\section{PEMBAHASAN}

Berkenaan dengan tujuan, penelitian ini dilakukan untuk mengetahui gambaran waktu pemotongan dan waktu pemesinan pada uji kompetensi praktik kejuruan bidang pemesinan bubut, serta mengetahui seberapa besarnya hubungan anatara waktu pemotongan dengan pemesinan bubut pada uji kompetensi praktik kejuruan bidang pemesinan di SMK Negeri 6 Bandung.

Setelah melakukan pengolahan data yang telah terkumpul, maka ditemukan gambaran rata-rata waktu pemotongan dan waktu pemesinan. Untuk gambaran mengenai waktu pemotongan pada pelaksanaan uji kompetensi praktik kejuruan bidang pemesinan bubut diperoleh waktu pemotongan rata-rata yang dilakukan oleh siswa selama 47,3 menit, waktu minimum/tercepat selama 22 menit dan waktu maksimum/terlama selama 118 menit. Sedangkan gambaran waktu pemesinan rata-rata yang dilakukan oleh siswa selama 212,5 menit, waktu minimum/tercepat 85 menit dan waktu maksimum/terlama 390 menit. Waktu pemesinan pada pelaksanaan uji kompetensi, yang ditunjukkan pada tabel 2 di bawah ini.

Tabel 2. Waktu pemesinan pada uji kompetensi kejuruan bidang pemesinan bubut

\begin{tabular}{cccccc}
\hline No & Kategori & Kriteria & Rentang & Frekuensi & $\%$ \\
\hline 1 & Sangat cepat & $\mathrm{A} \leq \overline{\mathrm{X}}-\mathrm{SD}$ & $\mathrm{A} \leq 151,7$ & 4 & 13 \\
2 & Cepat & $\overline{\mathrm{X}}-S D<\mathrm{B} \leq \overline{\mathrm{X}}-\frac{1}{2} S D$ & $151,7<\mathrm{B} \leq 182,1$ & 4 & 13 \\
3 & Sedang & $\overline{\mathrm{X}}-\frac{1}{2} S D<\mathrm{C} \leq \overline{\mathrm{X}}+\frac{1}{2} \mathrm{SD}$ & $182,1<\mathrm{C} \leq 242,9$ & 13 & 43 \\
4 & Lambat & $\overline{\mathrm{X}}+\frac{1}{2} \mathrm{SD}<\mathrm{D} \geq \overline{\mathrm{X}}+\mathrm{SD}$ & $242,9<\mathrm{D} \leq 273,3$ & 7 & 24 \\
5 & Sangat lambat & $\mathrm{E}>\overline{\mathrm{X}}+\mathrm{SD}$ & $\mathrm{E}>273,3$ & 2 & 7 \\
& & Jumlah & & 30 & 100 \\
\hline
\end{tabular}

Pembuatan kategori dibuat menjadi 5 kriteria penilaian siswa terhadap waktu pemotongan, dari 5 kriteria tersebut diperoleh 4 siswa mendapat nilai A (sangat cepat), 4 
siswa mendapat nilai B (cepat), 13 siswa mendapat nilai C (sedang), 7 siswa mendapat nilai D (lambat) dan 2 siswa mendapat nilai E (sangat lambat).

Hasil tersebut menunjukkan bahwa hasil proses pembelajaran untuk aspek waktu pemesinan siswa belum mampu dikatakan berhasil, karena rata-rata siswa berada pada interval kategori sedang. Hasil ini memperlihatkan bahwa keterampilan siswa dalam melakukan pekerjaan praktik kejuruan ini belum mumpuni dan menggambarkan hasil pencapaian belajar yang kurang baik. Ada beberapa indikator yang mempengaruhi ketidak tercapaian penilaian waktu kerja secara maksimal. Secara tidak langsung yang mempengaruhi waktu kerja adalah pada sistem evaluasi yang dilakuakan. Salah satu contohnya ialah tidak adanya standar patokan penilaian waktu yang jelas dan spesifik dalam uji kompetensi praktik kejuruan khususnya dalam proses menggunakan mesin bubut, sehingga siswa kurang merespon dan memperhatikan terhadap pekerjaan yang akan dilakukan.

Berdasarkan hasil penilaian yang dilakukan oleh asesor untuk aspek waktu ini, terdapat perbedaan hasil penilaian yang penulis temukan. Penilaian waktu kerja siswa pada pelaksanaan uji kompetensi praktik kejuruan pemesinan di SMK Negeri 6 Bandung Tahun Pelajaran 2013/2014, semua siswa mendapat nilai A atau mendapatkan skore 4. Apabila dilihat dari hasil penilaian yang dilakukan asesor dapat dikatakan bahwa semua siswa dikatakan berhasil atau kompeten. Jika ditinjau dari segi evaluasi yang merupakan tolak ukur kemampuan siswa, maka ini jelas tidak berhasil. Pada pelaksanaan di lapangan dan sesuai dengan kriteria penilaian yang penulis rancang masih terdapat beberapa siswa yang belum kompeten pada uji kompetensi bidang pemesinan bubut terutama pada aspek waktu kerja. Jika dilihat standar penilaian pada aspek waktu kerja yang ditetapkan oleh BSNP, maka hasil penilaian tersebut jalas berbeda dengan yang penulis lakukan. Ini terjadi karena kriteria penilaian yang ditetapkan BSNP hanya berupa kategori tepat dan tidak tepat waktu yang dihubungkan dengan hasil pekerjaan.

Apabila merujuk pada definisi uji kompetensi yang ditetapkan oleh Permendiknas Nomor 70 tahun 2008, bahwa uji kompetensi adalah proses pengujian dan penilaian yang dilakukan oleh penguji atau asesor uji kompetensi untuk mengukur tingkat pencapaian kompetensi hasil belajar peserta didik. Penilaian yang dilakukan asesor harus lebih objektif dalam menentukan kriteria penilaian yang mana dapat membedakan siswa yang kompeten dan siswa yang belum kompeten. Sehingga pihak sekolah mengetahui gambaran berapa besar siswa yang berkompeten dibidang pemesinan dan yang kurang kompeten dibidang pemesinan terutama pada bidang pemesinan bubut. Dengan demikian dapat dilakukan 
beberapa upaya untuk meningkatkan ketercapaian hasil pembelajaran siswa khususnya dalam bidang praktik kejuruan.

Dilihat pada komponen waktu pemesinan ini terdiri dari beberapa aspek, memaparkan, bahwa kegiatan operator yang produktif pada proses pemesinan membubut diantaranya meliputi waktu aktif memotong (mengawasi mesin yang bekerja) sebesar $36,2 \%$, waktu mesin yang tidak memotong atau nonproduktif (memasang benda kerja, penyiapan, pengakhiran, pengambilan produk) sebesar 13,4\%, waktu mengganti pahat sebesar 1,9\% dan waktu mengukur benda kerja (pada atau di luar mesin) sebesar 5,6\%. Sehingga muncul persamaan untuk mengetahui waktu pemesinan $\left(T_{m}\right)$ yaitu $T_{m}=2,7 T_{c}$ (Rochim, 1993). Dapat diasumsikan bahwa waktu pemotongan dapat mempengaruhi lamanya waktu pemesinan. Bila kita kaitkan dengan hasil waktu pemotongan dan waktu pemesinan yang telah dilakukan siswa pada uji kompetensi bidang pemesinan bubut, dengan hasil yang didapat waktu pemotongan rata-rata yang dilakukan oleh siswa selama 47,3 menit dan waktu pemesinan rata-rata selama 212,5 menit. Setelah dihasilkannya ratarata waktu pemotongan dan waktu pemesinan maka didapat persamaan waktu pemesinan $\left(\mathrm{T}_{\mathrm{m}}\right)$ yang dilakukan oleh siswa yaitu $\mathrm{T}_{\mathrm{m}}=4,5 \mathrm{~T}_{\mathrm{c}}$. Dari persamaan tersebut jelas terlihat bahwasannya waktu pemesinan yang dilakukan siswa lebih lama, hal ini dapat dipengaruhi oleh beberapa faktor yang dapat mempengaruhi waktu pemesinan yang dilakukan siswa menjadi lebih lama, diantaranya siswa kurang memperhatikan parameter-parameter pemotongan dan siswa terlalu sering melakukan kegiatan non produktif.

Kembali pada perbandingan waktu pemesinan yang terlihat dari persamaan di atas, dapat terlihat bahwa hasil waktu pemesinan yang dilakukan oleh siswa lebih lama dibandingankan dengan waktu waktu pemesinan yang dilakukan oleh operator industri. Perbedaan tersebut dapat disebabkan oleh beberapa faktor, antara lain teknologi yang diterapkan di sekolah dan di industri pasti berbeda. Teknologi yang diterapkan di sekolah belum secanggih teknologi yang digunakan di industri, seperti hal nya dalam menggunakan jenis bahan pahat bubut dan teknologi mesin bubut (Susilana, 2006). Penggunaan bahan pahat bubut yang biasa digunakan oleh sekolah dalam proses pemesinan bubut ialah jenis bahan pahat baja berkecepatan tinggi atau HSS (high speed steel). Sedangkan yang biasa digunakan operator di industri menggunakan jenis pahat bubut berbahan karbida. Selain itu dalam teknologi pemasangan alat pun berbeda, bila di sekolah setiap proses pengerjaan siswa harus mengganti pahat tersebut dengan pahat sesuai pengerjaannya. Hal lain yang dapat mempengaruhi lamanya waktu pemesinan yaitu perbedaan keterampilan (skill) yang dimiliki oleh operator industri dengan siswa sekolah (Sanjaya, 2011). Operator di industri 
lebih berpengalaman dalam menangani pekerjaan-pekerjaan pembubutan. Sehingga operator mesin bubut di industri lebih terampil dalam mengatur aspek waktu pemesinan. Sedangkan siswa selaku calon operator masih harus lebih diberi waktu untuk berlatih dalam tahap agar kompetensi siswa dalam melakukan proses bubut ini menjadi lebih terampil. Selain itu faktor yang membedakan ialah tujuan dalam praktik yang dilakukan oleh operator dan siswa jelas berbeda. Bahwasanya tujuan operator dalam melakukan praktik tersebut adalah untuk membuat sebuah produk tertentu dengan melakukan perencanaan dan analisis proses terlebih dahulu sehingga para operator lebih efektif dalam mempergunakan waktu kerjanya, sedangkan siswa hanya dituntut melakukan kerja praktik yang bertujuan untuk mengetahui seberapa besar kompetensi siswa tersebut dalam menguasai dan mengimplementasikan teori pada bidang pemesinan terutama proses membubut. Sehingga siswa tidak memiliki kesempatan untuk melakukan perencanaan dan analisis proses yang berdampak pengerjaan proses pembubutan siswa lebih lama dibandingkan dengan operator (Warsita, 2008).

Perencanaan dan analisis proses (estimasi) waktu pemotongan dan waktu pemesinan pada masing-masing proses pekerjaan membubut pada pelaksanaan uji kompetensi praktik kejuruan. Estimasi waktu pemotongan dan waktu pemesinan dilakukan berdasarkan perhitungan dalam menentukan waktu pemotongan, dapat dihitung dengan menentukan panjang pemesinan ( $\mathrm{mm}$ ) dibagi dengan kecepatan makan ( $\mathrm{mm} /$ putaran). Hal ini dilakukan untuk mengetahui waktu standar yang dibutuhkan oleh siswa dalam pelaksanaan uji kompetensi praktik kejuruan bidang pemesinan bubut (Zainal, 2012).

Setelah pengolahan data dilakukan, pada uji koefisien korelasi spearman diperoleh nilai $r=0,60$ nilai $r$ tersebut berada pada kategori tingkat hubungan kuat. Hal ini diartikan bahwa terdapat hubungan yang kuat antara waktu pemotongan dengan waktu pemesinan pada uji kompetensi praktik kejuruan bidang pemesinan bubut.

Implikasi dar hasil penelitian ini, yaitu diharapkan guru atau asesor membuat perencanaan dan analisis proses perngerjaan bubut untuk menentukan waktu standar agar dapat menentukan kriteria penilaian yang maksimal. Dengan demikian format kriteria penilaian yang digunakan dapat lebih objektif sehingga berguna untuk memudahkan asesor dalam menilai peserta uji kompetensi dan dapat dijadikan sebagai acuan atau faktor pembeda untuk mengetahui antara siswa yang kompeten dan belum kompeten. Selain itu dalam rangka meningkatkan kompetensi siswa sebagai calon operator di industri pemesinan (Muslich, 2011). Kemampuan siswa dalam kegiatan praktik perlu ditingkatkan, 
Salah satunya pada aspek waktu kerja, sehingga siswa mampu memaksimalkan kemampuan untuk melakukan pekerjaan dengan lebih baik.

\section{KESIMPULAN}

Berdasarkan hasil penelitian yang telah dilakukan, dapat diambil kesimpulan waktu pemotongan pada pelaksanan uji kompetensi praktik kejuruan bidang pemesinan bubut diperoleh, waktu minimum/tercepat 22 menit, waktu maksimum/terlama 118 menit dan rata-rata waktu pemotongan 47,3 menit. Selain itu, waktu pemesinan pada pelaksanaan uji kompetensi praktik kejuruan bidang pemesinan bubut diperoleh, waktu minimum/tercepat 85 menit, waktu maksimum/terlama 390 menit dan rata-rata waktu pemesinan 212,5 menit. Waktu pemotongan berhubungan dengan waktu pemesinan pada uji kompetensi praktik kejuruan bidang pemesinan bubut dengan kategori hubungan kuat. Waktu pemotongan berbanding lurus dengan waktu pemesinan, apabila waktu pemotongan lebih lama, dapat diprediksi waktu pemesinan pun akan semakin lama.

\section{DAFTAR PUSTAKA}

Dimyanti dan Mudjiono. (2013). Belajar dan Pembelajaran. Jakarta: Rineka Cipta.

Fajaryati, N. (2012). Evaluasi Pelaksanaan Teaching Factory SMK di Surakarta. Jurnal Pendidikan Vokasi, 2 (3).

Muslich, M. (2011). KTSP Pembelajaran Berbasis Kompetensi dan Kontekstual. Jakarta: Bumi Aksara.

Rochim, T. (1993). Teori dan Teknologi Proses Pemesinan. Bandung: Lab. Teknik Produksi Jurusan Teknik Mesin FTI - ITB.

Sanjaya, W. (2011). Pembelajaran dalam Implementasi Kurikulum Berbasis Kompetensi. Jakarta: Kencana.

Susilana, R. (2006). Kurikulum dan Pembelajaran. Bandung: Jurusan Kurikulum Teknologi Pendidikan FIP UPI.

Triyono, E. (2012). Potret Sekolah Kejuruan. Penelitian di Jurusan Teknik Elektro Politeknik Negeri Semarang. Jurnal Teknis, 7 (2).

Warsita, B. (2008). Teknologi Pembelajaran. Jakarta: Rineka Cipta.

Zainal, A. (2012). Evaluasi Pembelajaran. Bandung: PT. Remaja Rosdakarya. 